\title{
Effect of tsunami load on the elementary school building of the 23/24 Padang, Indonesia
}

\author{
Fauzan Fauzan ${ }^{1}$, Khin Thu Zar Htay ${ }^{1,2}$, Zawil Huda $^{1}$, Hafiz Oktaufik ${ }^{1}$, and Geby Aryo Agista ${ }^{1}$ \\ ${ }^{1}$ Department of Civil Engineering, Faculty of Engineering, University of Andalas, Padang, Indonesia \\ ${ }^{2}$ Nay Pyi Taw Development Committee, NAY PYI TAW, Myanmar
}

\begin{abstract}
West Sumatra Province is one of the provinces in Indonesia that is vulnerable to natural disasters, especially earthquakes and tsunamis. Padang city, as the capital city of West Sumatra, is an area that is included in an area with a high level of vulnerability (High Risk Zone) to tsunamis. Therefore, the construction of public buildings such as hospitals, government offices, and school buildings must have certain technical engineering that is able to anticipate the damage and collapse of buildings due to the earthquake and tsunami. One of the public buildings as an educational facility in Padang city is the Elementary School building of the 23/24 (SD 23/24 Padang), located close to the beach. Based on the evaluation results of the Detail Engineering Design (DED) documents, it is found that this building was designed without taking into account the tsunami loads. Therefore, a building assessment should be carried out to check the capacity of the building to resist the working loads, including the tsunami loads, and to investigate the effect of the tsunami loads on the SD 23/24 Padang building. In this study, the building was analyzed using ETABS v.18 software based on the new Indonesian Seismic Code, SNI 1726-2019 for seismic load and FEMA P646-2019 for calculating tsunami loads. The results show that the SD 23/24 Padang building is strong against earthquake loads, but it doesn't have enough capacity when tsunami loads are applied, in which there are several structural elements (columns/beams) that do not have sufficient capacity to withstand the combined earthquake and tsunami loads. The effect of tsunami loads on the building structure is also discussed in this paper.
\end{abstract}

\section{Introduction}

West Sumatra Province is one of the provinces in Indonesia that is vulnerable to natural disasters, especially earthquakes and tsunamis [1]. This is because West Sumatra is traversed by three sources of earthquake threat : the Sumatra Fault Zone, the subduction zone that is a meeting between the India-Australia tectonic plates and the Eurasian plate, and the Mentawai Fault Zone $[1,2]$. Major earthquakes have occurred several times, one of which was a major earthquake on September 30, 2009, in Padang city, West Sumatra, with a magnitude of 7.6 on the Richter Scale [3]. Although it did not cause a tsunami, the devastating earthquake that hit the coast of West Sumatra has killed around 1700 people and damaged more than 200,000 buildings [3].

Padang city, as the capital city of West Sumatra, is an area that is included in the area with a high level of vulnerability (High Risk Zone) to tsunami [4]. Therefore, the construction of public facilities such as hospitals, government offices, sport centers, and school buildings must have certain technical engineering that is able to anticipate the damage and collapse of buildings due to the earthquake and tsunami [5]. One of the public facilities in Padang city as an educational facility is the SD 23/24 Padang building.

SD 23/24 Padang has been operating since January 1, 1976 , where this school building is owned by the local government.

The SD 23/24 Padang building consists of three buildings which are three-story and two-story reinforced concrete buildings. Based on the evaluation results of the Detail Engineering Design (DED) documents, this building was designed without taking into account the tsunami loads. This building is located close to the beach, which will have an impact in the event of an earthquake with a potential tsunami. Therefore, a building assessment should be carried out to check the capacity of the building to resist the working loads, including the tsunami loads, and to investigate the effect of the tsunami loads on the SD 23/24 Padang building.

\footnotetext{
* Corresponding author: fauzan@eng.unand.ac.id
} 


\section{Building's data and analysis}

\subsection{Location of the building}

Fig. 1 shows the location of SD 23/24 Padang on Veteran street No. 90, Padang, West Sumatra by using Google Earth, where this building is located at a distance of \pm 474 $\mathrm{M}$ from the beach.

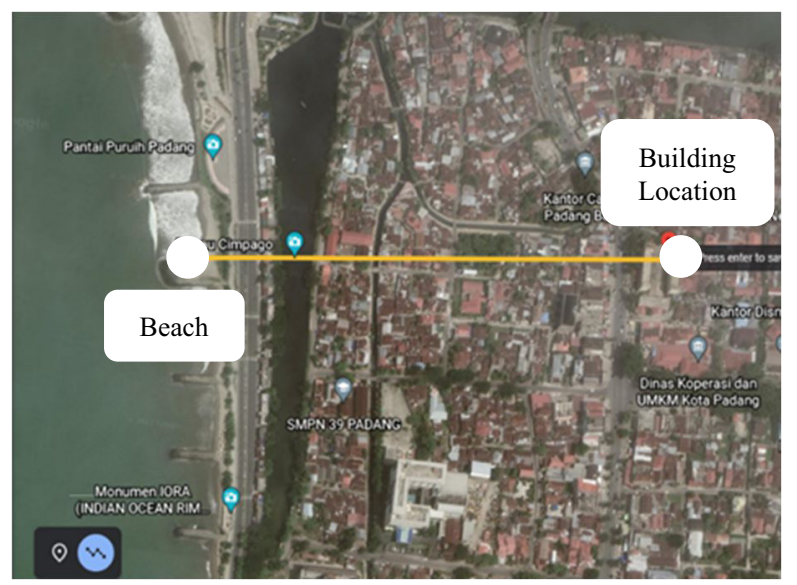

Fig. 1. The Location Of The SD 23/24 Padang Building (Google Earth)

The location of the building is also in the vicinity of urban areas, offices, and densely populated residential areas.

\subsection{Tsunami vulnerability level}

Based on the tsunami-prone zone map of Padang city shown in Fig. 2, the SD 23/24 Padang building is located in the West Padang area, an area with a high level of vulnerability (High Risk Zone) to tsunamis [1].

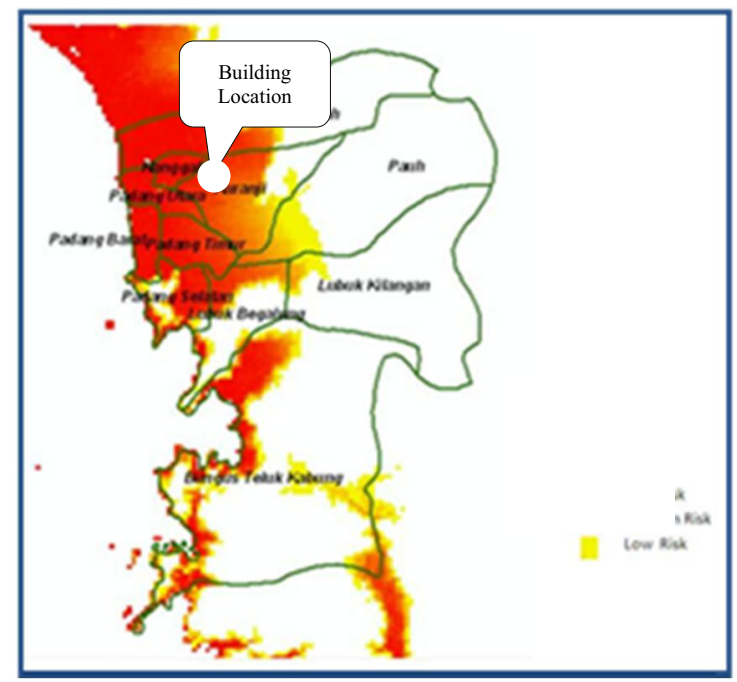

Fig. 2. Tsunami-Prone Zone Of Padang City

\subsection{Building structure data}

The parameters used in the structural analysis are the technical data of the building and the existing condition of the building obtained from the field survey by LPPM expert of Andalas University with the following data:
Building Name
: SD 23/24 Padang
Location
: Veteran street No.90 Ujung
Distance from the beach Gurun, Padang
Number of building stories : 3 stories
Height between floors $\quad: 4.00 \mathrm{~m}$
Height above sea level $\quad: 0.80 \mathrm{~m}$

Table 1 shows the cross-sectional dimensions of columns and beams of the SD 23/24 Padang building. The plan and front view and of the building can be seen in Figs. 3 and 4.

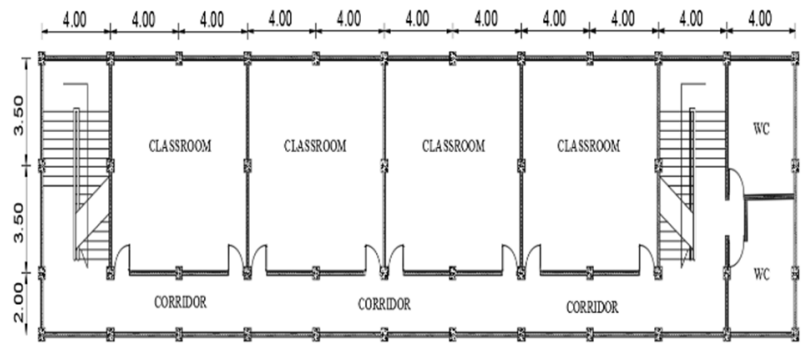

a. First and Second Floor Plans

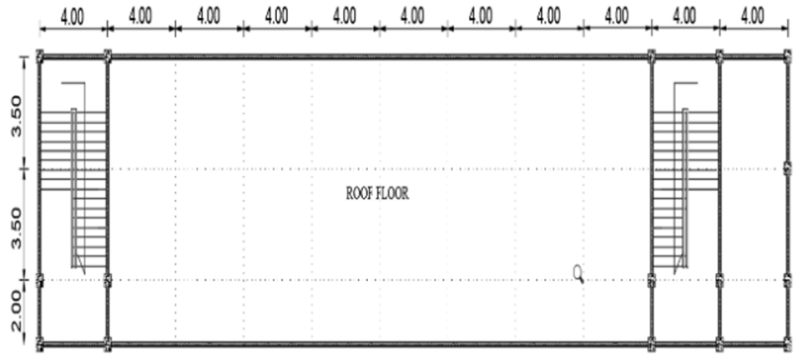

b. Third Floor Plan

Fig. 3. Plan of SD 23/24 Padang Building

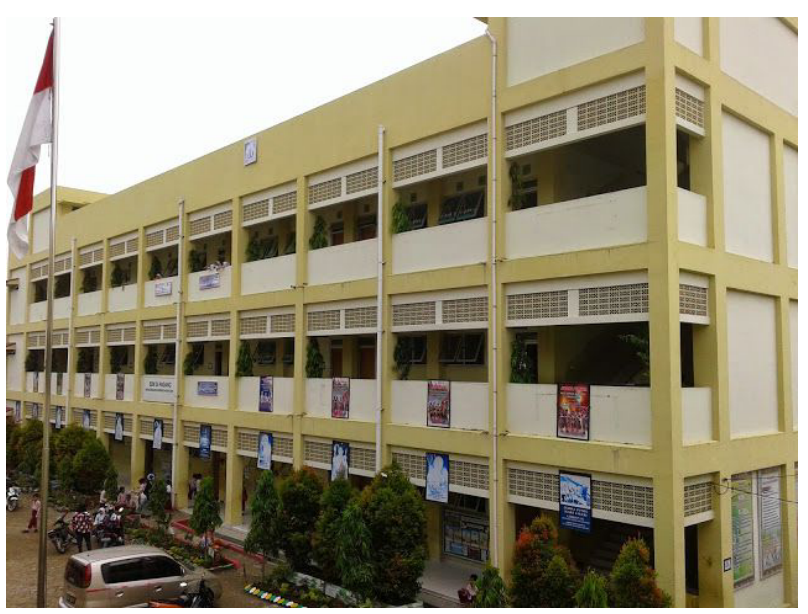

Fig. 4. Front View of SD 23/24 Padang Building 
Table 1. Column and beam dimensions

\begin{tabular}{|c|c|c|c|}
\hline \multirow{2}{*}{ No } & \multirow{2}{*}{$\begin{array}{c}\text { Column } \\
\text { Code }\end{array}$} & \multicolumn{2}{|c|}{ Dimension } \\
\cline { 3 - 4 } & & Height (mm) & Width (mm) \\
\hline 1 & C4 & 450 & 450 \\
\hline 2 & C5 & 350 & 350 \\
\hline 3 & C6 & 450 & 350 \\
\hline 4 & CS & 250 & 250 \\
\hline \hline \multirow{2}{*}{ No } & \multirow{2}{*}{ Beam } & \multicolumn{2}{|c|}{ Dimension } \\
\cline { 3 - 4 } & Code & Height (mm) & Width (mm) \\
\hline 1 & $1 G 1$ & 700 & 300 \\
\hline 2 & $1 G 2$ & 550 & 300 \\
\hline 3 & $1 G 3$ & 500 & 450 \\
\hline 1 & $2 G 1$ & 700 & 300 \\
\hline 2 & $2 \mathrm{G} 2$ & 500 & 300 \\
\hline 3 & $2 \mathrm{G} 3$ & 450 & 450 \\
\hline 1 & RG1 & 700 & 300 \\
\hline 2 & RG2 & 500 & 300 \\
\hline 3 & RG3 & 450 & 350 \\
\hline
\end{tabular}

\subsection{Modeling of the building structure}

The SD 23/24 Padang building structure was analyzed using software ETABS v.18 with 3D modeling. The columns and beams of the building structure are modeled as frames, the slab is modeled as a slab element, and the shear wall is modeled as a wall element. The modeling is carried out according to the current condition of the SD 23/24 Padang building. The structural analysis of SD 23/24 Padang building is conducted into two load conditions, namely:

a. Buildings are only subjected to live, dead and earthquake loads.

b. Buildings are subjected to live, dead, earthquake and tsunami loads.

All structural elements such as beams, columns, slabs, and shear walls are modeled in the ETABS v.18 structural analysis application, as shown in Fig. 5.

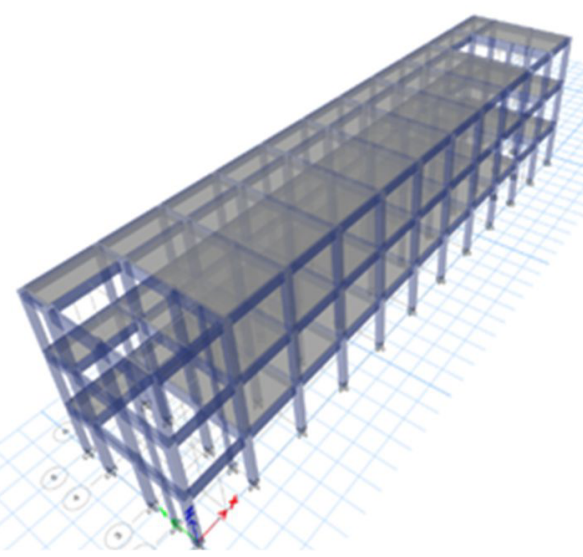

Fig. 5. Modeling of the Building Structure

\subsection{Loads analysis}

\subsubsection{Dead load}

Dead loads on the SD 23/24 Padang building are:

a. Self-weight of structural elements was calculated directly by structural analysis program ETABS v. 18

b. Flooring material ( $1 \mathrm{~cm}$ thickness)

$1 \times 48 \mathrm{~kg} / \mathrm{m}^{2}=48 \mathrm{~kg} / \mathrm{m}^{2}$

c. Flooring mortar ( $2 \mathrm{~cm}$ thickness)

$2 \times 21 \mathrm{~kg} / \mathrm{m}^{2}=42 \mathrm{~kg} / \mathrm{m}^{2}$

d. Ceiling Weight

$1 \times 20 \mathrm{~kg} / \mathrm{m} 2=20 \mathrm{~kg} / \mathrm{m}^{2}$

Total $=110 \mathrm{~kg} / \mathrm{m}^{2}$

$$
=1,078 \mathrm{~kg} / \mathrm{m}^{2} \approx 1,1 \mathrm{kN} / \mathrm{m}^{2}[6]
$$

Self-weight of building materials and components refers to Article 3.1.1, SNI 1727:2020, "Minimum load for designing buildings and other structures" [7].

\subsubsection{Live load}

Based on Article 4.3.1, SNI 1727:2020, the live load on the SD 23/24 Padang building is taken as $1.92 \mathrm{kN} / \mathrm{m}^{2}$ for classrooms and $4.79 \mathrm{kN} / \mathrm{m}^{2}$ for corridor [7].

\subsubsection{Earthquake load}

Analysis of the structure of the SD 23/24 Padang building uses an earthquake response analysis approach to the dynamic response spectrum. The response spectrum of the earthquake plan for the structural analysis of this building can be seen in Table 2. Earthquake loading is calculated based on the new Indonesian Seismic Code, SNI 1726:2019 (Earthquake Resistance Planning Procedures for Building and Non-Building Structures) [8]. Fig. 6 shows the response Spectrum Design of Padang City.

Table 2. Response spectrum parameters

\begin{tabular}{|c|c|c|c|}
\hline No & Data & Variabel & Nilai \\
\hline 1 & Risk Category Office Buildings & $\mathrm{K}$ & Category N \\
\hline 2 & Priority Factors for Earthquake & I & 1.5 \\
\hline \multirow{3}{*}{3} & Parameters of Land Acceleration (Ss, S1) & & \\
\hline & $\begin{array}{l}\text { a. Acceleration of MCE Spectral Response } \\
\text { from Earthquake Map in Short Period }\end{array}$ & SS & 1.500 \\
\hline & $\begin{array}{l}\text { b. MCE Spectral Response Acceleration from } \\
\text { Earthquake Map in } 1 \text { second Period }\end{array}$ & S1 & 0.600 \\
\hline 4 & Location Class/Site Classification & $\mathrm{KS}$ & Medium (SD) \\
\hline \multirow{3}{*}{5} & Site Coefficient Factor (Fa,Fv) & & \\
\hline & a. Site coefficient for short period & $\mathrm{Fa}$ & 1.000 \\
\hline & b. Site Coef for long period & Fv & 1.700 \\
\hline \multirow{3}{*}{6} & $\begin{array}{l}\text { Acceleration Spectrum Response } \\
\text { Parameters (SMS and SM1) }\end{array}$ & & \\
\hline & $\begin{array}{l}\text { a. MCE Spectral Response Acceleration } \\
\text { Short }\end{array}$ & SMS & 1.500 \\
\hline & $\begin{array}{l}\text { b. MCE Spectral Response Acceleration } \\
\text { Period } 1 \text { second adjusted for site class (SM1 }\end{array}$ & SM1 & 1.020 \\
\hline \multirow{3}{*}{7} & $\begin{array}{l}\text { Design Spectral Acceleration Parameters } \\
\text { (SDS and SD1) }\end{array}$ & & \\
\hline & $\begin{array}{l}\text { a. Acceleration of Spectral Response in a } \\
\text { Short Period (SDS }=2 / 3 \text { SMS }\end{array}$ & SDS & 1.000 \\
\hline & $\begin{array}{l}\text { b. Acceleration Spectral Response Over a } \\
\text { period of } 1 \text { second (SD1 = 2/3 SM1) }\end{array}$ & SD1 & 0.680 \\
\hline \multirow{3}{*}{8} & Design Response Spectrum Time & & \\
\hline & a. $\mathrm{T}_{0}=0,2 \mathrm{SD} 1 / \mathrm{SDS}$ & $\mathrm{T}_{0}$ & 0.136 \\
\hline & B. Ts $=\mathrm{SD} 1 / \mathrm{SDS}$ & $\mathrm{T}_{\mathrm{s}}$ & 0.680 \\
\hline 9 & Seismic Design Category & KDS & $\mathrm{D}$ \\
\hline
\end{tabular}




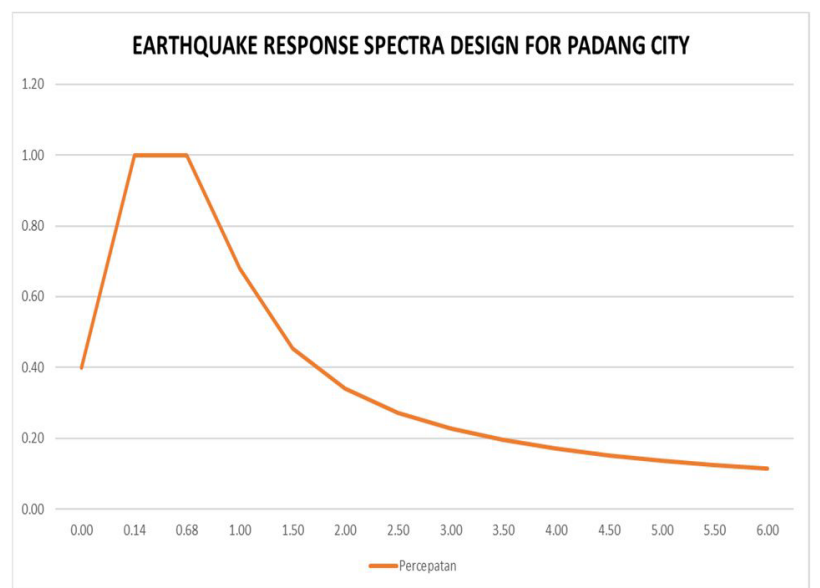

Fig. 6. Response Spectra Design of Padang City

\subsubsection{Tsunami load}

The calculation of the tsunami load is conducted based on the FEMA P646-2019 "Guidelines for Design of Structures for Vertical Evacuation from Tsunamis" [9]. There are several types of tsunami loads that are taken into account in the structural analysis, where the magnitude of each load value is calculated based on the predicted tsunami wave height, subgrade elevation of the design area, distance to the coast $[10,11]$, as shown in Fig. 7.

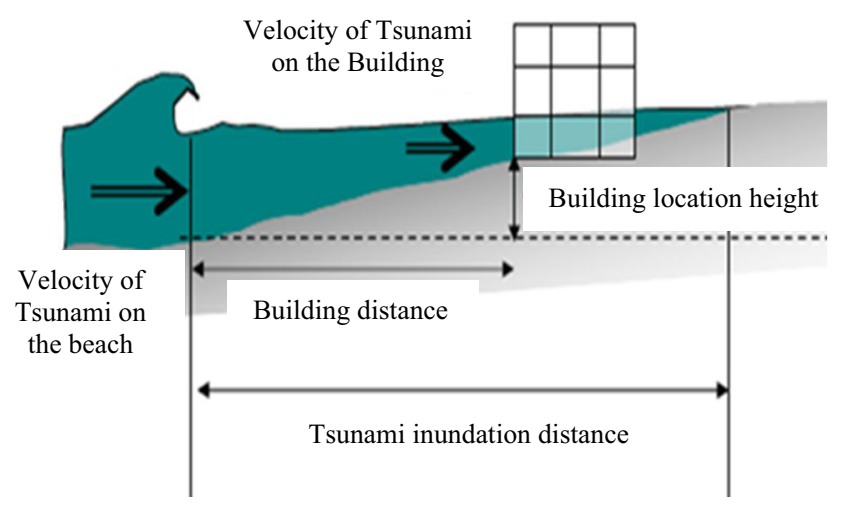

Fig. 7. Sketch of Tsunami Inundation

According to point 8.7 FEMA-2019, it is explained that not all tsunami loads affect the structural components of a building dépends on the layout of the building [9]. In this study, the tsunami loads calculated in this building are illustrated in Figs. $8-10$.

a. Hydrostatic Force

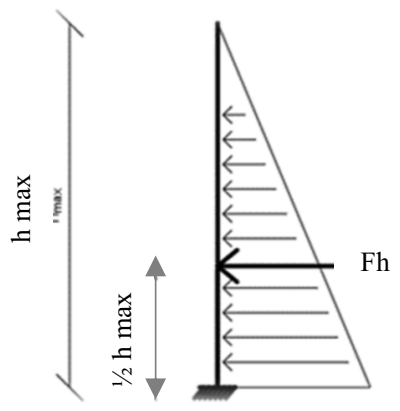

Fig. 8. Tsunami Hydrostatic Force

$$
F_{h}=\frac{1}{2} \rho_{S} \times g \times b \times h_{\max ^{2}}
$$

The fluid density including sediment, $\rho_{S}=1100 \mathrm{~kg} / \mathrm{m}^{3}$

The breadth (width) of the wall, $b=4 \mathrm{~m}$

The gravitational acceleration $g \quad=9,81 \mathrm{~m} / \mathrm{s}^{2}$

The maximum water height, $h_{\max } \quad=5,7 \mathrm{~m}$

$$
F_{h}=78.885 \mathrm{kN}
$$

b. Hydrodynamic Force

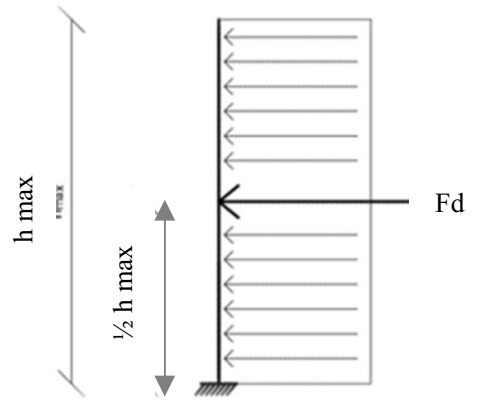

Fig. 9. Tsunami Hydrodynamic Force

$$
F_{d}=\frac{1}{2} \rho_{S} x c_{d} x\left(h u^{2}\right)_{\max }
$$

The drag coefficient, $c_{d}=2$

$F_{d}=20,053 k N$

c. Impulse Force

$$
\begin{aligned}
F_{d} & =1.5 F_{d} \\
& =30.080 \mathrm{kN}
\end{aligned}
$$

d. Force Due to Debris Impact

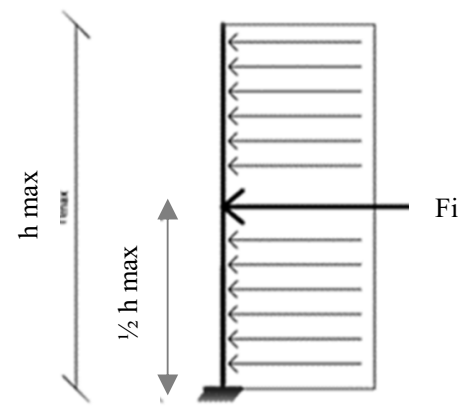

Fig. 10. The Force Due to the Impact of the Tsunami Debris

$$
F_{i}=1,3 u_{\max } x \sqrt{\left[k m_{d}(1+c)\right]}
$$

The maximum flow velocity, $u_{\max } \quad=10.575 \mathrm{~m} / \mathrm{s}$ Mass of the debris , $m_{d} \quad=450 \mathrm{~kg}$ Hydrodynamic mass coefficient, $c \quad=2$ The effective net combined stiffness, $k=2400000 \mathrm{~N} / \mathrm{m}$

$$
F_{i}=782.533 k N
$$




\subsection{Loads combination}

Structural loads combination refers to the New Indonesian Seismic Code (SNI 1726:2019) [4]:

1. $1,4 \mathrm{D}$

2. $1,2 D+1,6 L+0,5(L r$ or $R)$

3. $1,2 D+1,6(L r$ atau $R)+(L$ or $0,5 W)$

4. $1,2 D+1,0 W+L+0,5(L r$ or $R)$

5. $0,9 \mathrm{D}+1,0 \mathrm{~W}$

6. $1,2 D+E V+E H+L$

7. $0,9 D-E V+E H$

Combination of tsunami loads acting on the structure refers to FEMA P-646 [8]:

1. $1,2 \mathrm{DL}+1,0 \mathrm{TS}+1,0$ Lref $+0,25 \mathrm{LL}$

2. $0,9 D L+1,0 T S$

Where:

$D L=$ Dead Load

$L L=$ Live Load

$L r \quad=$ Live Load on the Roof

$W=$ Wind Load

$R \quad=$ Rain Load

$E Q X=$ Earthquake Load on $\mathrm{X}$ Direction

$E Q Y=$ Earthquake Load on Y Direction

$E V=0,2$ SDS $\times \mathrm{D}$

$E H=$ Rho $\mathrm{x} \mathrm{QE}$

Rho $=1,3$ (Redundancy)

$T s \quad=$ Tsunami Load

Lref $=$ Live Load in Refuge Area

The loading combination in this analysis is shown in Table 3.

\section{Results and discussion}

\subsection{Inter story drift}

\subsubsection{Inter story drift of the building}

Based on article 7.8.6 of SNI 1726:2019, the determination of inter story drift $(\Delta)$ must be calculated as the difference in the deviation at the center of mass above and below the level under consideration [8]. Table 4 shows the results of inter story drift for the SD 23/24 Padang building.

From Table 4, it can be seen that the inter story drift in the $\mathrm{X}$ and $\mathrm{Y}$ directions, without and with the Tsunami loads, are still in the allowable range. The increase in maximum inter story drift due to the tsunami loads in the $\mathrm{X}$ direction and $\mathrm{Y}$ direction is $118.75 \%$ and $77.67 \%$, respectively.

\subsection{Structural sectional capacity}

\subsubsection{Coulomn sectional capacity}

To determine the capacity of the column in carrying the load, it can be observed from the column interaction diagram [12 - 14]. The P-M interaction diagram is a diagram that describes the capability or capacity of the column based on the relationship between the moment and the axial load of the column $[15,16]$. The P-M interaction diagrams of building columns without and with tsunami loads are shown in Figs. 11 and 12.

From Fig. 11, it can be seen that the column on the 1st floor of the building is strong enough to carry the working loads because the axial moment and compression forces do not outside the design axial moment line.

While when tsunami loads are added, the column on the 1st floor of the building is not strong enough to carry the working loads because there are axial moment and compression force that passes through the design axial moment line, as shown in Fig. 12.

Table 3. Load Combination

\begin{tabular}{|c|c|c|c|c|c|c|c|c|c|c|c|}
\hline \multicolumn{12}{|c|}{ Earthquake Load Combination } \\
\hline 1 & 1.4 & DL & & & & & & & & & \\
\hline 2 & 1.2 & $\mathrm{DL}$ & + & 1.6 & $\mathrm{LL}$ & & & & & & \\
\hline 3 & 1.378 & DL & + & 1 & $\mathrm{LL}$ & + & 1.3 & EQX & + & 0.39 & EQY \\
\hline 4 & 1.378 & $\mathrm{DL}$ & + & 1 & $\mathrm{LL}$ & + & 1.3 & $\mathrm{EQX}$ & - & 0.39 & EQY \\
\hline 5 & 1.378 & DL & + & 1 & $\mathrm{LL}$ & - & 1.3 & EQX & + & 0.39 & EQY \\
\hline 6 & 1.378 & DL & + & 1 & $\mathrm{LL}$ & - & 1.3 & EQX & - & 0.39 & EQY \\
\hline 7 & 1.378 & DL & + & 1 & $\mathrm{LL}$ & + & 0.39 & EQX & + & 1.3 & EQY \\
\hline 8 & 1.378 & DL & + & 1 & $\mathrm{LL}$ & + & 0.39 & EQX & - & 1.3 & EQY \\
\hline 9 & 1.378 & DL & + & 1 & $\mathrm{LL}$ & - & 0.39 & EQX & + & 1.3 & EQY \\
\hline 10 & 1.378 & DL & + & 1 & $\mathrm{LL}$ & - & 0.39 & EQX & - & 1.3 & EQY \\
\hline 11 & 0.722 & DL & + & 1.3 & EQX & + & 0.39 & EQY & & & \\
\hline 12 & 0.722 & DL & + & 1.3 & EQX & - & 0.39 & EQY & & & \\
\hline 13 & 0.722 & DL & - & 1.3 & EQX & + & 0.39 & EQY & & & \\
\hline 14 & 0.722 & DL & - & 1.3 & EQX & - & 0.39 & EQY & & & \\
\hline 15 & 0.722 & DL & + & 0.39 & EQX & + & 1.3 & EQY & & & \\
\hline 16 & 0.722 & $\mathrm{DL}$ & + & 0.39 & EQX & $\cdot$ & 1.3 & EQY & & & \\
\hline 17 & 0.722 & $\mathrm{DL}$ & - & 0.39 & EQX & + & 1.3 & EQY & & & \\
\hline 18 & 0.722 & DL & - & 0.39 & EQX & - & 1.3 & EQY & & & \\
\hline 19 & Envelope & & & & & & & & & & \\
\hline \multicolumn{12}{|c|}{ Tsunami Load Combination } \\
\hline 1 & 1.2 & $\mathrm{DL}$ & + & 0.25 & $\mathrm{LL}$ & + & 1 & Ts & + & 1 & Lref \\
\hline 2 & 0.9 & $\mathrm{DL}$ & + & 1 & Ts & & & & & & \\
\hline
\end{tabular}

Table 4. Inter story drift of the building on $\mathrm{X}$ and $\mathrm{Y}$ directions without and with tsunami load

\begin{tabular}{|c|c|c|c|c|c|}
\hline \multirow{2}{*}{ Story } & $\begin{array}{c}\text { Without Tsunami } \\
\text { Load }\end{array}$ & $\begin{array}{c}\text { With Tsunami } \\
\text { Load }\end{array}$ & $\begin{array}{c}\text { Delta } \\
\text { Limit }\end{array}$ & CHECK & $\begin{array}{c}\text { Percentage } \\
\text { Increase }\end{array}$ \\
\cline { 2 - 5 } & $\Delta \mathrm{x}(\mathrm{mm})$ & $\Delta \mathrm{x}(\mathrm{mm})$ & $\mathrm{mm}$ & $\begin{array}{c}\Delta \text { Izin }> \\
\Delta \mathrm{x}\end{array}$ & $\mathrm{mm}$ \\
\hline 3 & 12.04 & 26.33 & 40.00 & $\mathrm{OK}$ & $118.75 \%$ \\
\hline 2 & 20.03 & 39.65 & 40.00 & $\mathrm{OK}$ & $97.96 \%$ \\
\hline 1 & 16.84 & 30.02 & 40.00 & OK & $78.26 \%$ \\
\hline 0 & 0.00 & 0 & 0 & - & $0.00 \%$ \\
\hline
\end{tabular}

\begin{tabular}{|c|c|c|c|c|c|}
\hline \multirow{3}{*}{ Story } & $\begin{array}{c}\text { Without Tsunami } \\
\text { Load }\end{array}$ & $\begin{array}{c}\text { With Tsunami } \\
\text { Load }\end{array}$ & $\begin{array}{c}\text { Delta } \\
\text { Limit }\end{array}$ & CHECK & $\begin{array}{c}\text { Percentage } \\
\text { Increase }\end{array}$ \\
\cline { 2 - 5 } & $\Delta \mathrm{x}(\mathrm{mm})$ & $\Delta \mathrm{x}(\mathrm{mm})$ & $\mathrm{mm}$ & $\begin{array}{c}\Delta \text { Izin }> \\
\Delta \mathrm{x}\end{array}$ & $\mathrm{mm}$ \\
\hline 3 & 9.33 & 16.57 & 40.00 & $\mathrm{OK}$ & $77.67 \%$ \\
\hline 2 & 16.83 & 29.22 & 40.00 & $\mathrm{OK}$ & $73.61 \%$ \\
\hline 1 & 16.56 & 26.88 & 40.00 & $\mathrm{OK}$ & $62.31 \%$ \\
\hline 0 & 0 & 0 & 0 & - & $0.00 \%$ \\
\hline
\end{tabular}




\section{- Without Tsunami}

First Floor P-M Interaction Diagram
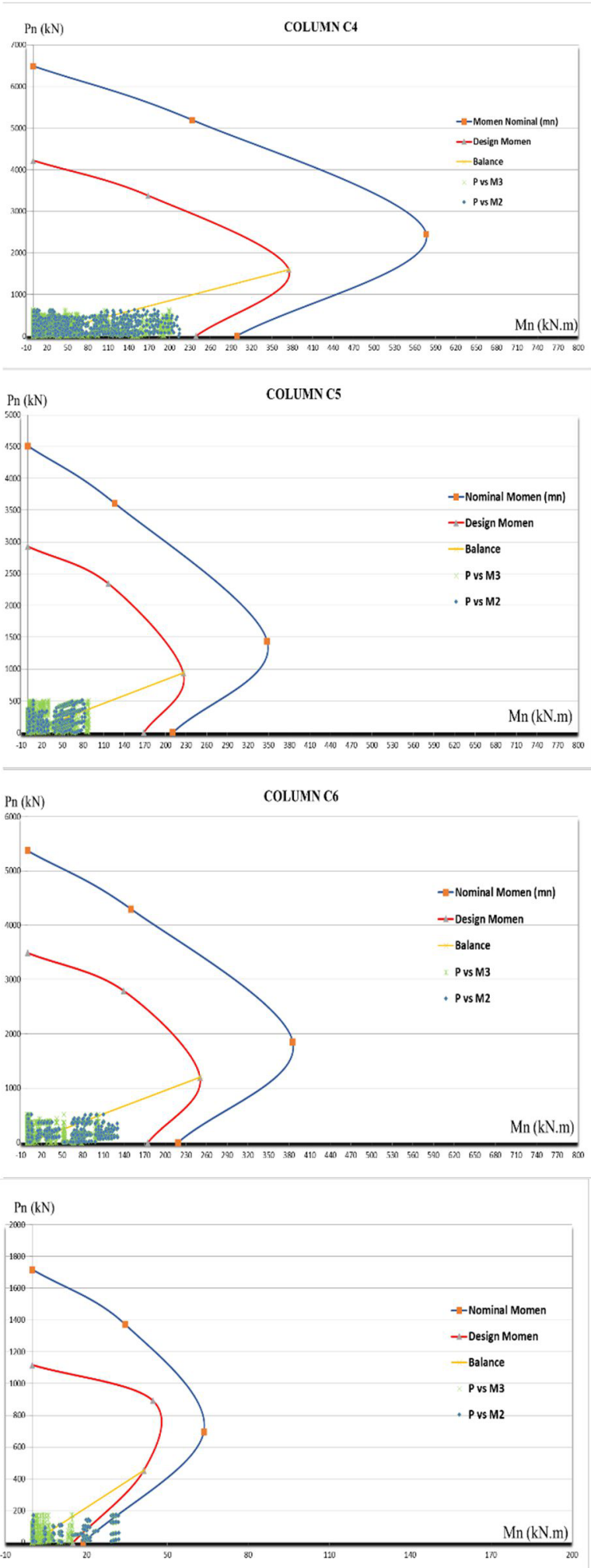

Fig. 11. Interaction Diagram of Column on 1st Floor Building Without Tsunami Load

\section{- With Tsunami}

$\underline{\text { First Floor P-M Interaction Diagram }}$

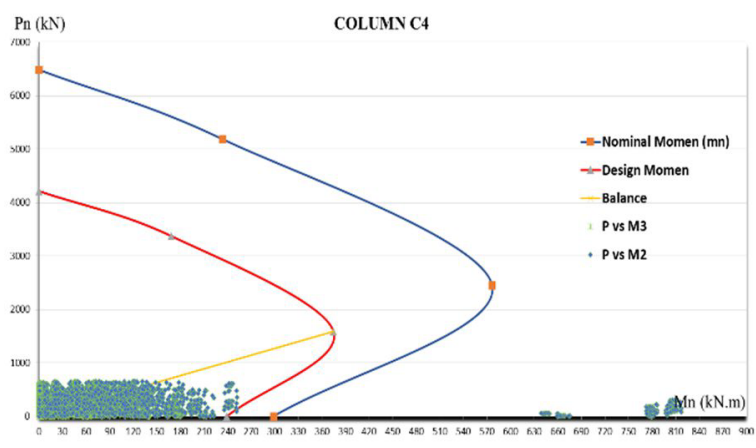

COLUMN C5
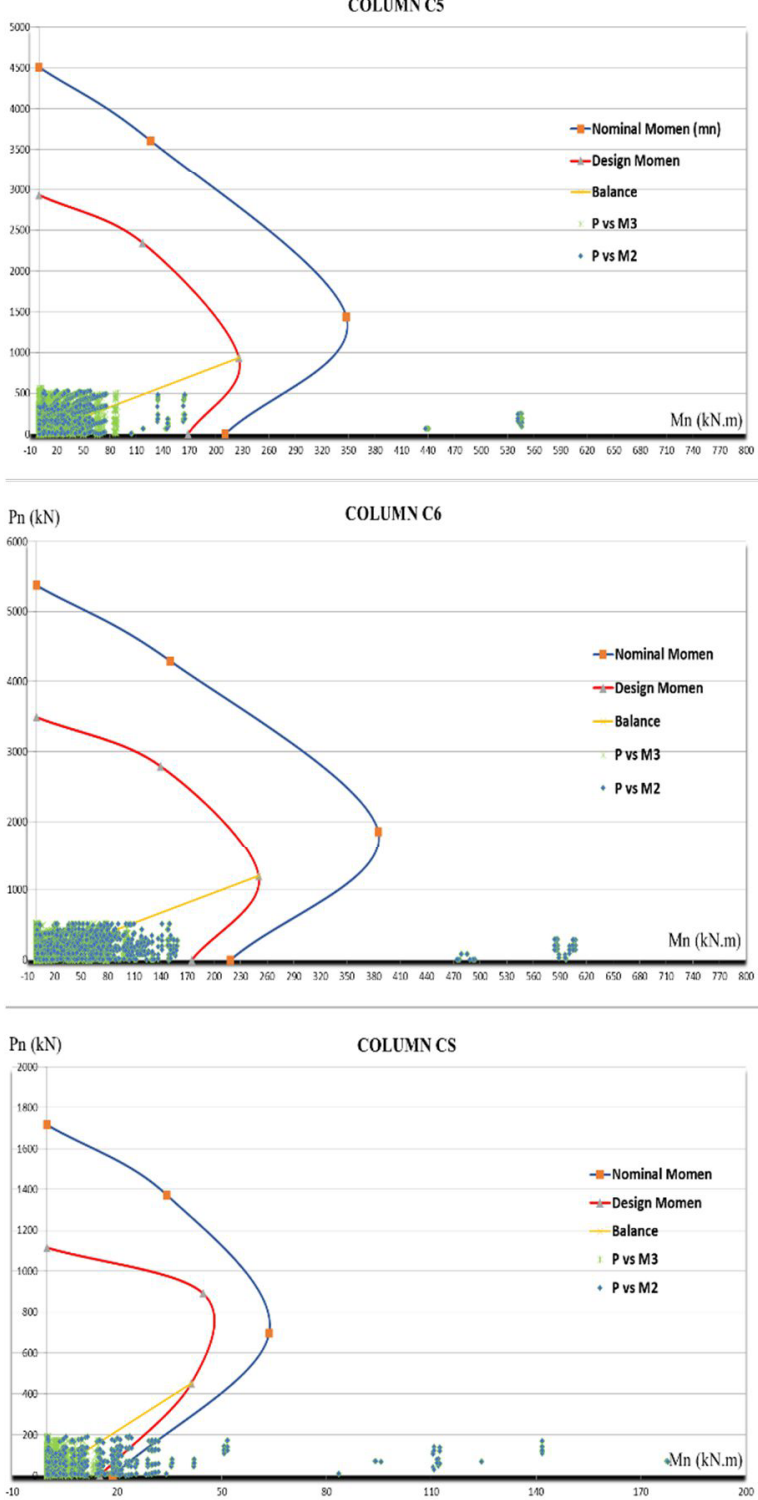

Fig. 12. Interaction Diagram of Column on 1st floor of Building with Tsunami Load

The calculation results of the column shear capacity without and with tsunami load are shown in Tables 5 and 6. 
Table 5. Column shear capacity of the building without tsunami load

\begin{tabular}{|c|c|c|c|c|c|c|c|}
\hline & \multirow[t]{2}{*}{$\begin{array}{c}\text { Column } \\
\text { Type }\end{array}$} & $\begin{array}{c}\text { Cross- } \\
\text { Section } \\
\text { dimention }\end{array}$ & $\begin{array}{l}\text { Stirup } \\
\text { Diameter }\end{array}$ & $\begin{array}{c}\text { Distance } \\
\text { between } \\
\text { Stirrup }\end{array}$ & $\Phi \mathrm{Vn}$ & $\mathrm{Vu}$ & Note \\
\hline & & $(B \times H) \mathrm{mm}$ & $(\mathrm{mm})$ & $(\mathrm{mm})$ & $(\mathrm{kN})$ & (kN) & \\
\hline \multirow{4}{*}{ 1st Floor } & C4 & $450 \times 450$ & 10 & 100 & 345.731 & 110.413 & OK \\
\hline & $\mathrm{C5}$ & $350 \times 350$ & 10 & 100 & 239.129 & 42.900 & OK \\
\hline & $\mathrm{C6}$ & $450 \times 350$ & 10 & 100 & 261.406 & $\begin{array}{l}75.316 \\
\end{array}$ & OK \\
\hline & CS & $250 \times 250$ & 10 & 100 & 146.899 & $\begin{array}{l}19.083 \\
\end{array}$ & OK \\
\hline & & & & & & & \\
\hline \multirow{4}{*}{ 2nd Floor } & C4 & $450 \times 450$ & 10 & 100 & 345.731 & \begin{tabular}{|c|}
85.277 \\
\end{tabular} & OK \\
\hline & $\mathrm{C} 5$ & $350 \times 350$ & 10 & 100 & 239.129 & 33.364 & OK \\
\hline & $\mathrm{C} 6$ & $450 \times 350$ & 10 & 100 & 261.406 & 72.908 & OK \\
\hline & CS & $250 \times 250$ & 10 & 100 & 146.899 & 20.662 & OK \\
\hline & & & & & & & \\
\hline \multirow{4}{*}{ 3rd Floor } & C4 & $450 \times 450$ & 10 & 100 & 345.731 & 42.120 & OK \\
\hline & $\mathrm{C} 5$ & $350 \times 350$ & 10 & 100 & 239.129 & 13.277 & OK \\
\hline & $\mathrm{C} 6$ & $450 \times 350$ & 10 & 100 & 261.406 & 41.309 & OK \\
\hline & CS & $250 \times 250$ & 10 & 100 & 146.899 & \begin{tabular}{|c|}
11.091 \\
\end{tabular} & OK \\
\hline
\end{tabular}

As seen in Table 5, the building columns are able to withstand the shear forces acting on the structure.

Table 6. Column shear capacity of the building with tsunami load

\begin{tabular}{|c|c|c|c|c|c|c|c|}
\hline & \multirow[t]{2}{*}{$\begin{array}{c}\text { Column } \\
\text { Type }\end{array}$} & $\begin{array}{c}\text { Cross- } \\
\text { Section } \\
\text { dimention } \\
\end{array}$ & $\begin{array}{c}\text { Stiriup } \\
\text { Diameter }\end{array}$ & $\begin{array}{c}\text { Distance } \\
\text { between } \\
\text { Stirrup } \\
\end{array}$ & $\Phi \mathrm{Vn}$ & $\mathrm{Vu}$ & Note \\
\hline & & $(B \times H) \mathrm{mm}$ & $(\mathrm{mm})$ & $(\mathrm{mm})$ & (kN) & $(\mathrm{kN})$ & \\
\hline & C4 & $450 \times 450$ & 10 & 100 & 345.731 & 716.812 & NOT OK \\
\hline $1 \mathrm{ct} F \mathrm{ror}$ & $\mathrm{C} 5$ & $350 \times 350$ & 10 & 100 & 239.129 & 271.705 & NOT OK \\
\hline Ist Floor & $\mathrm{C} 6$ & $450 \times 350$ & 10 & 100 & 261.406 & 359.573 & NOT OK \\
\hline & CS & $250 \times 250$ & 10 & 100 & 146.899 & 177.263 & NOT OK \\
\hline & & & & & & & \\
\hline & C4 & $450 \times 450$ & 10 & 100 & 345.731 & 88.734 & OK \\
\hline 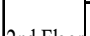 & $\mathrm{C} 5$ & $350 \times 350$ & 10 & 100 & 239.129 & 35.755 & OK \\
\hline Znd Floc & C6 & $450 \times 350$ & 10 & 100 & 261.406 & 75.522 & OK \\
\hline & CS & $250 \times 250$ & 10 & 100 & 146.899 & 22.131 & OK \\
\hline & & & & & & 5 5 577 & \\
\hline & $\mathrm{C} 5$ & $350 \times 350$ & 10 & 100 & $\mid \frac{J 4 . / 11}{239.129}$ & $\begin{array}{l}16.534 \\
16734\end{array}$ & $O_{K}$ \\
\hline $3 \mathrm{Fd} \mathrm{Fl001}$ & C6 & $450 \times 350$ & 10 & 100 & 261.406 & 44.766 & OK \\
\hline & CS & $250 \times 250$ & 10 & 100 & 146.899 & 14.548 & OK \\
\hline
\end{tabular}

Table 7. Percentage change in shear capacity of building columns due to tsunami load

\begin{tabular}{|c|c|c|c|c|}
\hline & \multirow{2}{*}{$\begin{array}{l}\text { Column } \\
\text { Type }\end{array}$} & \multicolumn{2}{|c|}{$\mathrm{Vu}(\mathrm{kN})$} & \multirow{2}{*}{$\begin{array}{l}\text { Percentage } \\
\text { Increase }\end{array}$} \\
\hline & & Without Tsunami Load & Without Tsunami Load & \\
\hline \multirow{4}{*}{ 1st Floor } & $\mathrm{C} 4$ & 110.413 & 716.812 & $549.21 \%$ \\
\hline & $\mathrm{C} 5$ & 42.900 & 271.705 & $533.35 \%$ \\
\hline & C6 & 75.316 & 359.573 & $377.42 \%$ \\
\hline & CS & 19.083 & 177.263 & $828.92 \%$ \\
\hline \multirow{4}{*}{ 2nd Floor } & $\mathrm{C} 4$ & 85.277 & 88.734 & $4.05 \%$ \\
\hline & $\mathrm{C} 5$ & 33.364 & 35.755 & $7.17 \%$ \\
\hline & C6 & 72.908 & 75.522 & $3.59 \%$ \\
\hline & $\mathrm{CS}$ & 20.662 & 22.131 & $7.11 \%$ \\
\hline \multirow{4}{*}{ 3rd Floor } & $\mathrm{C} 4$ & 42.120 & 45,577 & $8.21 \%$ \\
\hline & $\mathrm{C} 5$ & 13.277 & 16.734 & $26.04 \%$ \\
\hline & $\mathrm{C} 6$ & 41.309 & 44.766 & $8.37 \%$ \\
\hline & $\mathrm{CS}$ & 11.091 & 14.548 & $31.17 \%$ \\
\hline
\end{tabular}

While the columns on the 1st floor of the building are unable to withstand the shear forces acting on the structure due to the addition of the tsunami loads, as shown in Table 6.

From Table 7, it can be seen that the 1st floor column experienced an increase in the maximum shear force due to the influence of the tsunami load of $828.92 \%$.

\subsubsection{Capacity of beams}

\section{a. Bending capacity of beams}

The calculation results of beam flexural capacity without and with tsunami load can be seen in Tables 8 and 9 .

Table 8. Bending capacity of building beam without tsunami load

\begin{tabular}{|c|c|c|c|c|c|c|c|c|c|}
\hline & \multirow{2}{*}{$\begin{array}{l}\text { BEAM } \\
\text { TYPE }\end{array}$} & \multirow{2}{*}{$\begin{array}{c}\text { Cross-Section } \\
\text { dimention }\end{array}$} & \multirow{2}{*}{ Note } & \multicolumn{2}{|c|}{$\emptyset \mathrm{Mn}(\mathrm{kN})$} & \multicolumn{2}{|c|}{$\mathrm{Mu}(\mathrm{kN})$} & \multicolumn{2}{|c|}{$\emptyset \mathrm{Mn} \geq \mathrm{Mu}$} \\
\hline & & & & Positive & Negative & Positive & Negative & Positive & Negative \\
\hline \multirow{6}{*}{ 1st Floor } & \multirow{2}{*}{$1 \mathrm{Gl}$} & \multirow{2}{*}{$30 \times 70$} & At Support & 252.68 & 252.68 & 214.83 & 216.86 & OK & OK \\
\hline & & & At Field & 252.68 & 252.68 & 138.75 & 134.12 & OK & OK \\
\hline & \multirow{2}{*}{$1 \mathrm{G} 2$} & \multirow{2}{*}{$30 \times 55$} & At Support & 145.85 & 145.85 & 141.65 & 157.44 & OK & NOT OK \\
\hline & & & At Field & 145.85 & 145.85 & 76.10 & 73.55 & OK & OK \\
\hline & \multirow{2}{*}{193} & \multirow{2}{*}{$45 \times 50$} & At Support & $\mid 130.96$ & 130.96 & 130.42 & 134.28 & OK & NOT OK \\
\hline & & & At Field & \begin{tabular}{|l|}
130.96 \\
\end{tabular} & 130.96 & 71.70 & 69.17 & OK & OK \\
\hline & & & & & & & & & \\
\hline \multirow{6}{*}{ 2nd Floor } & \multirow{2}{*}{$2 \mathrm{Gl}$} & \multirow{2}{*}{$30 \times 70$} & At Support & 190.50 & \begin{tabular}{|l|l|}
190.50 \\
\end{tabular} & 141.86 & 151.06 & OK & OK \\
\hline & & & At Field & 190.50 & 190.50 & 95.92 & 98.22 & OK & OK \\
\hline & \multirow{2}{*}{$2 \mathrm{G} 2$} & \multirow{2}{*}{$30 \times 50$} & At Support & $\mid$\begin{tabular}{|l|}
130.96 \\
\end{tabular} & 130.96 & 97.61 & 117.50 & OK & OK \\
\hline & & & At Field & 130.96 & 130.96 & 55.77 & 50.27 & OK & OK \\
\hline & \multirow{2}{*}{$2 \mathrm{G} 3$} & \multirow{2}{*}{$45 \times 45$} & At Support & 118.07 & 118.07 & 79.92 & 99.03 & OK & OK \\
\hline & & & At Field & 118.07 & \begin{tabular}{|l|}
118.07 \\
\end{tabular} & 50.42 & 43.40 & OK & OK \\
\hline \multirow{7}{*}{ 3rd Floor } & \multirow{3}{*}{ RGI } & \multirow{3}{*}{$30 \times 70$} & & & & & & & \\
\hline & & & At Support & 190.50 & 190.50 & 61.30 & 75.56 & OK & OK \\
\hline & & & At Field & 190.50 & 190.50 & 43.74 & 59.33 & $\mathrm{OK}$ & OK \\
\hline & \multirow{2}{*}{ RG2 } & \multirow{2}{*}{$30 \times 50$} & At Support & 130.96 & 130.96 & 53.83 & 72.39 & $0 \mathrm{~K}$ & OK \\
\hline & & & At Field & 130.96 & 130.96 & 36.09 & 28.08 & OK & OK \\
\hline & \multirow{2}{*}{ RG3 } & \multirow{2}{*}{35 X 45} & At Support & 116.08 & 116.08 & 33.81 & 41.29 & $\mathrm{OK}$ & $\mathrm{OK}$ \\
\hline & & & At Field & 116.08 & 116.08 & 25.80 & 17.81 & OK & OK \\
\hline
\end{tabular}

Table 9. Bending capacity of building beams with tsunami load

\begin{tabular}{|c|c|c|c|c|c|c|c|c|c|}
\hline & \multirow{2}{*}{$\begin{array}{l}\text { BEAM } \\
\text { TYPE }\end{array}$} & \multirow{2}{*}{$\begin{array}{c}\text { Cross-Section } \\
\text { dimention }\end{array}$} & \multirow{2}{*}{ Note } & \multicolumn{2}{|c|}{$\emptyset \mathrm{Mn}(\mathrm{kN})$} & \multicolumn{2}{|c|}{$\mathrm{Mu}(\mathrm{kN})$} & \multicolumn{2}{|c|}{$\emptyset \mathrm{Mn} \geq \mathrm{Mu}$} \\
\hline & & & & Positive & Negative & Positive & Negative & Positive & Negative \\
\hline \multirow{6}{*}{ 1st Floor } & \multirow{2}{*}{$1 \mathrm{Gl}$} & \multirow{2}{*}{$30 \times 70$} & \begin{tabular}{|l|} 
At Support \\
\end{tabular} & 252.68 & 252.68 & 227.46 & 229.49 & $\mathrm{OK}$ & OK \\
\hline & & & At Field & 252.68 & 252.68 & 170.92 & 146.75 & $\mathrm{OK}$ & $\mathrm{OK}$ \\
\hline & \multirow{2}{*}{$1 \mathrm{G} 2$} & \multirow{2}{*}{$30 \times 55$} & At Support & 145.85 & 145.85 & 148.95 & 164.73 & $\mathrm{OK}$ & NOT OK \\
\hline & & & At Field & 145.85 & 145.85 & 83.39 & 80.84 & $\mathrm{OK}$ & $\mathrm{OK}$ \\
\hline & \multirow{2}{*}{$1 \mathrm{G} 3$} & \multirow{2}{*}{$45 \times 50$} & At Support & 130.96 & 130.96 & 136.96 & 140.83 & $\mathrm{OK}$ & NOT OK \\
\hline & & & At Field & 130.96 & 130.96 & 78.82 & 75.72 & $\mathrm{OK}$ & $\mathrm{OK}$ \\
\hline & & & & & & & & & \\
\hline \multirow{6}{*}{ 2nd Floor } & \multirow{2}{*}{$2 \mathrm{Gl}$} & \multirow{2}{*}{$30 \times 70$} & At Support & 190.50 & 190.50 & 147.58 & 156.77 & $\mathrm{OK}$ & OK \\
\hline & & & At Field & 190.50 & 190.50 & 101.63 & 103.94 & OK & OK \\
\hline & \multirow{2}{*}{$2 \mathrm{G} 2$} & \multirow{2}{*}{$30 \times 50$} & At Support & 130.96 & 130.96 & 101.54 & 121.43 & $\mathrm{OK}$ & $\mathrm{OK}$ \\
\hline & & & At Field & 130.96 & 130.96 & 59.70 & 54.20 & $\mathrm{OK}$ & $\mathrm{OK}$ \\
\hline & \multirow{2}{*}{$2 \mathrm{G} 3$} & \multirow{2}{*}{$45 \times 45$} & At Support & 118.07 & 118.07 & 83.46 & 102.57 & OK & OK \\
\hline & & & At Field & 118.07 & 118.07 & 53.96 & 46.95 & $\mathrm{OK}$ & $\mathrm{OK}$ \\
\hline & & & & & & & & & \\
\hline \multirow{6}{*}{ 3rd Floor } & \multirow{2}{*}{ RGl } & \multirow{2}{*}{$30 \times 70$} & \begin{tabular}{|l|} 
At Support \\
\end{tabular} & 190.50 & 190.50 & 63.20 & 77.47 & $\mathrm{OK}$ & $\mathrm{OK}$ \\
\hline & & & At Field & 190.50 & 190.50 & 45.64 & 61.24 & $\mathrm{OK}$ & $\mathrm{OK}$ \\
\hline & \multirow{2}{*}{ RG2 } & \multirow{2}{*}{$30 \times 50$} & At Support & 130.96 & 130.96 & 55.14 & 73.70 & $\mathrm{OK}$ & $\mathrm{OK}$ \\
\hline & & & At Field & 130.96 & 130.96 & 37.40 & 29.39 & OK & OK \\
\hline & \multirow{2}{*}{ RG3 } & \multirow{2}{*}{$35 \times 45$} & At Support & 116.08 & 116.08 & 34.97 & 42.45 & OK & OK \\
\hline & & & At Field & 116.08 & 116.08 & 26.96 & 18.97 & $\mathrm{OK}$ & $\mathrm{OK}$ \\
\hline
\end{tabular}


As can be seen in Tables 8 and 9, almost all the beams in the building without and with tsunami loads are able to withstand the working loads, but some beam structural elements do not have sufficient capacity to withstand the earthquake and tsunami loads, that are the 1G2 and 1G3 beams.

Table 10. Percentage change in bending capacity of building block due to tsunami load

\begin{tabular}{|c|c|c|c|c|c|c|c|c|}
\hline & \multirow{3}{*}{$\begin{array}{l}\text { BEAM } \\
\text { TYPE }\end{array}$} & \multirow{3}{*}{ Note } & \multicolumn{4}{|c|}{$\mathrm{Mu}(\mathrm{kN})$} & \multirow{2}{*}{\multicolumn{2}{|c|}{ Percentage Increas }} \\
\hline & & & \multicolumn{2}{|c|}{ Without Tsunami Load } & \multicolumn{2}{|c|}{ WithTsunami Load } & & \\
\hline & & & Positive & Negative & Positive & Negative & $\begin{array}{l}\text { Positive } \\
\end{array}$ & $\begin{array}{l}\text { Negative } \\
\end{array}$ \\
\hline \multirow{6}{*}{ 1st Floor } & \multirow{2}{*}{$1 \mathrm{Gl}$} & At Support & 214.83 & 216.86 & 227.46 & 229.49 & $5.88 \%$ & $5.83 \%$ \\
\hline & & \begin{tabular}{|l|} 
At Field \\
\end{tabular} & 138.75 & 134.12 & 170.92 & 146.75 & $23.19 \%$ & $9.42 \%$ \\
\hline & \multirow{2}{*}{$1 \mathrm{G} 2$} & At Support & 141.65 & 157.44 & 148.95 & 164.73 & $5.15 \%$ & $4.63 \%$ \\
\hline & & AtField & 76.10 & 73.55 & 83.39 & 80.84 & $9.58 \%$ & $9.92 \%$ \\
\hline & \multirow{2}{*}{$1 \mathrm{G} 3$} & At Support & 130.42 & 134.28 & 136.96 & 140.83 & $5.02 \%$ & $4.88 \%$ \\
\hline & & AtField & 71.70 & 69.17 & 78.82 & 75.72 & $9.93 \%$ & $9.47 \%$ \\
\hline & & & & & & & & \\
\hline \multirow{6}{*}{ 2nd Floor } & \multirow{2}{*}{$2 \mathrm{Gl}$} & At Support & 141.86 & 151.06 & 147.58 & 156.77 & $4.03 \%$ & $3.78 \%$ \\
\hline & & At Field & 95.92 & 98.22 & 101.63 & 103.94 & $5.96 \%$ & $5.82 \%$ \\
\hline & \multirow{2}{*}{$2 \mathrm{G} 2$} & At Support & 97.61 & 117.50 & 101.54 & 121.43 & $4.02 \%$ & $3.34 \%$ \\
\hline & & AtField & 55.77 & 50.27 & 59.70 & 54.20 & $7.04 \%$ & $7.81 \%$ \\
\hline & \multirow{2}{*}{$2 \mathrm{G} 3$} & At Support & 79.92 & 99.03 & 83.46 & 102.57 & $4.43 \%$ & $3.58 \%$ \\
\hline & & At Field & 50.42 & 43.40 & 53.96 & 46.95 & $7.03 \%$ & $8.16 \%$ \\
\hline & & & & & & & & \\
\hline \multirow{6}{*}{ 3rd Floor } & \multirow{2}{*}{ RG1 } & At Support & 61.30 & 75.56 & 63.20 & 77.47 & $3.11 \%$ & $2.52 \%$ \\
\hline & & AtField & 43.74 & 59.33 & 45.64 & 61.24 & $4.36 \%$ & $3.21 \%$ \\
\hline & \multirow{2}{*}{ RG2 } & At Support & 53.83 & 72.39 & 55.14 & 73.70 & $2.43 \%$ & $1.81 \%$ \\
\hline & & \begin{tabular}{|l} 
AtField \\
\end{tabular} & 36.09 & 28.08 & 37.40 & 29.39 & $3.63 \%$ & $4.66 \%$ \\
\hline & \multirow{2}{*}{ RG3 } & At Support & 33.81 & 41.29 & 34.97 & 42.45 & $3.43 \%$ & $2.81 \%$ \\
\hline & & AtField & 25.80 & 17.81 & 26.96 & 18.97 & $4.50 \%$ & $6.52 \%$ \\
\hline
\end{tabular}

From Table 10, it can be seen that due to the effect of the tsunami load on the building, there was no significant increase in the flexural capacity of the beams. The increase in the flexural capacity of the beams is $1.81 \%-23.19 \%$.

b. Shear Capacity of the beam

The calculation results of the shear capacity of the beams can be seen in Tables 11 and 12 .

Table 11. Shear capacity of building beams without tsunami load

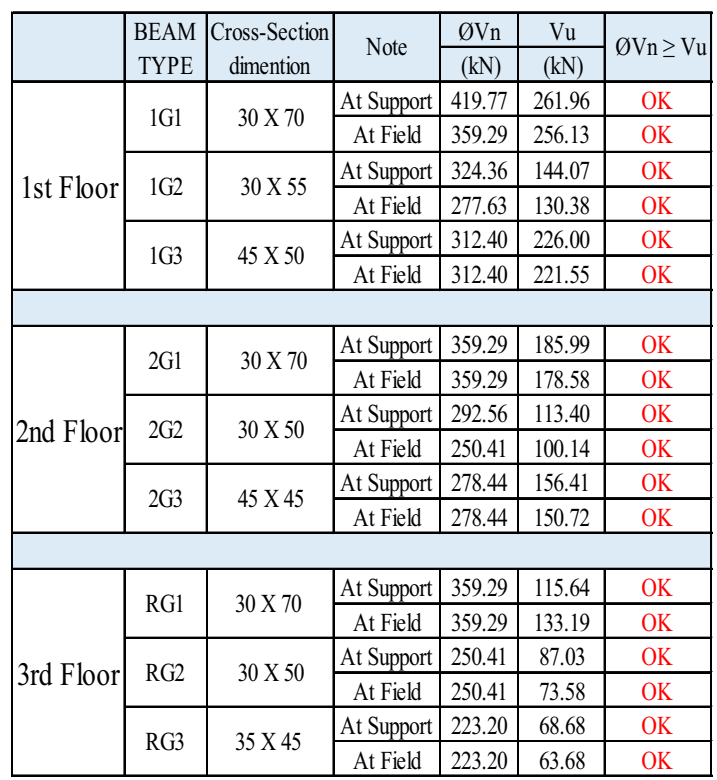

Table 12. Shear capacity of building beams with tsunami load

\begin{tabular}{|c|c|c|c|c|c|c|}
\hline & \multirow{2}{*}{$\begin{array}{l}\text { BEAM } \\
\text { TYPE }\end{array}$} & \multirow{2}{*}{$\begin{array}{c}\text { Cross-Section } \\
\text { dimention }\end{array}$} & \multirow{2}{*}{ Note } & $\varnothing \mathrm{Vn}$ & $\mathrm{Vu}$ & \multirow{2}{*}{$\varnothing \mathrm{Vn} \geq \mathrm{Vu}$} \\
\hline & & & & $(\mathrm{kN})$ & $(\mathrm{kN})$ & \\
\hline \multirow{6}{*}{ 1st Floor } & \multirow{2}{*}{$1 \mathrm{G} 1$} & \multirow{2}{*}{$30 \times 70$} & At Support & 419.77 & 385.58 & OK \\
\hline & & & At Field & 359.29 & 377.93 & NOT OK \\
\hline & \multirow{2}{*}{$1 \mathrm{G} 2$} & \multirow{2}{*}{$30 \times 55$} & At Support & 324.36 & 153.80 & $\mathrm{OK}$ \\
\hline & & & At Field & 277.63 & 138.71 & $\mathrm{OK}$ \\
\hline & \multirow{2}{*}{$1 \mathrm{G} 3$} & \multirow{2}{*}{$45 \times 50$} & At Support & 312.40 & 235.37 & $\mathrm{OK}$ \\
\hline & & & At Field & 312.40 & 230.92 & $\mathrm{OK}$ \\
\hline & & & & & & \\
\hline \multirow{6}{*}{ 2nd Floor } & \multirow{2}{*}{$2 \mathrm{Gl}$} & \multirow{2}{*}{$30 \times 70$} & At Support & 359.29 & 193.18 & $\mathrm{OK}$ \\
\hline & & & At Field & 359.29 & 185.77 & OK \\
\hline & \multirow{2}{*}{$2 \mathrm{G} 2$} & \multirow{2}{*}{$30 \times 50$} & At Support & 292.56 & 119.25 & $\mathrm{OK}$ \\
\hline & & & At Field & 250.41 & 105.15 & $\mathrm{OK}$ \\
\hline & \multirow{2}{*}{$2 \mathrm{G} 3$} & \multirow{2}{*}{$45 \times 45$} & At Support & 278.44 & 161.98 & $\mathrm{OK}$ \\
\hline & & & At Field & 278.44 & 156.29 & $\mathrm{OK}$ \\
\hline & & & & & & \\
\hline \multirow{6}{*}{ 3rd Floor } & \multirow{2}{*}{ RG1 } & \multirow{2}{*}{$30 \times 70$} & At Support & 359.29 & 119.23 & $\mathrm{OK}$ \\
\hline & & & At Field & 359.29 & 136.78 & $\mathrm{OK}$ \\
\hline & \multirow{2}{*}{ RG2 } & \multirow{2}{*}{$30 \times 50$} & \begin{tabular}{|l|} 
At Support \\
\end{tabular} & 250.41 & 89.54 & $\mathrm{OK}$ \\
\hline & & & At Field & 250.41 & 76.08 & $\mathrm{OK}$ \\
\hline & \multirow{2}{*}{ RG3 } & \multirow{2}{*}{$35 \times 45$} & At Support & 223.20 & 70.91 & $\mathrm{OK}$ \\
\hline & & & At Field & 223.20 & 65.92 & $\mathrm{OK}$ \\
\hline
\end{tabular}

As seen in Table 11, almost all beams in the building are able to withstand the loads acting on the structure. While one element of the beam (1G1) does not have sufficient capacity to withstand the working loads when the tsunami loads are applied (Table 12).

Table 13. Percentage change in shear capacity of building block due to tsunami load

\begin{tabular}{|c|c|c|c|c|c|}
\hline & \multirow[b]{2}{*}{$\begin{array}{l}\text { BEAM } \\
\text { TYPE }\end{array}$} & \multirow[b]{2}{*}{ Note } & \multicolumn{2}{|c|}{$\mathrm{Vu}(\mathrm{kN})$} & \multirow[b]{2}{*}{$\begin{array}{l}\text { Percentage } \\
\text { Increase }\end{array}$} \\
\hline & & & $\begin{array}{c}\text { Without Tsunami } \\
\text { Load }\end{array}$ & \begin{tabular}{|c}
$\begin{array}{c}\text { WithTsunami } \\
\text { Load }\end{array}$ \\
\end{tabular} & \\
\hline \multirow{6}{*}{ 1st Floor } & \multirow{2}{*}{$1 \mathrm{Gl}$} & At Support & 261.96 & 385.58 & $47.19 \%$ \\
\hline & & At Field & 256.13 & 377.93 & $47.56 \%$ \\
\hline & \multirow{2}{*}{$1 \mathrm{G} 2$} & At Support & 144.07 & 153.80 & $6.75 \%$ \\
\hline & & At Field & 130.38 & 138.71 & $6.39 \%$ \\
\hline & \multirow{2}{*}{$1 \mathrm{G} 3$} & At Support & 226.00 & 235.37 & $4.15 \%$ \\
\hline & & At Field & 221.55 & 230.92 & $4.23 \%$ \\
\hline & & & & & \\
\hline \multirow{6}{*}{ 2nd Floor } & \multirow{2}{*}{$2 \mathrm{Gl}$} & At Support & 185.99 & 193.18 & $3.86 \%$ \\
\hline & & At Field & 178.58 & 185.77 & $4.02 \%$ \\
\hline & \multirow{2}{*}{$2 \mathrm{G} 2$} & At Support & 113.40 & 119.25 & $5.16 \%$ \\
\hline & & At Field & 100.14 & 105.15 & $5.00 \%$ \\
\hline & \multirow{2}{*}{$2 \mathrm{G} 3$} & At Support & 156.41 & 161.98 & $3.56 \%$ \\
\hline & & At Field & 150.72 & 156.29 & $3.69 \%$ \\
\hline & & & & & \\
\hline \multirow{6}{*}{ 3rd Floor } & \multirow{2}{*}{ RGl } & At Support & 115.64 & 119.23 & $3.11 \%$ \\
\hline & & At Field & 133.19 & 136.78 & $2.70 \%$ \\
\hline & \multirow{2}{*}{$\mathrm{RG} 2$} & At Support & 87.03 & 89.54 & $2.88 \%$ \\
\hline & & At Field & 73.58 & 76.08 & $3.40 \%$ \\
\hline & \multirow{2}{*}{ RG3 } & At Support & 68.68 & 70.91 & $3.25 \%$ \\
\hline & & At Field & 63.68 & 65.92 & $3.50 \%$ \\
\hline
\end{tabular}

The effect of the tsunami load on the building shown in Table 13 shows that there was no significant increase in the load on the shear capacity of the beam. The load on the shear capacity of the beam increased by $2.70 \%-47.56$ $\%$. 


\section{Conclusion}

Based on this study, it can be concluded that:

1. SD 23/24 Padang building is strong against earthquake load, but it does not have enough capacity when tsunami loads are applied, in which there are several structural elements (columns/beams) that do not have sufficient capacity to withstand the combined earthquake and tsunami loads.

2. The addition of the tsunami loads on the SD 23/24 Padang building increases the inter story drift by around $78-119 \%$ in the $\mathrm{X}$ direction and $62-78 \%$ in the $\mathrm{Y}$ direction.

3. Due to the addition of the tsunami loads, there was an increase in the maximum column shear force around $828.92 \%$.

4. In beam elements, there is a maximum increase in bending and shear forces due to the addition of tsunami loads, which are around $23.19 \%$ and $47.56 \%$, respectively.

Acknowledgments to Civil Engineering Department, Engineering Faculty, Andalas University, which has funded this research with the contract number: 123/UN16.09.D/PL/2021.

\section{Reference}

1. National Center for Earthquake Studies, Source and Hazard Map of the 2017 Indonesian Earthquake, Bandung, Ministry of PUPR (2019)

2. B. Bambang et al. Examples of Earthquake Resistant Building Designs, Bandung: ITB (2017)

3. O. Dian, S. Manurung, Geospatial Model of Potential Tsunami Vulnerability in Padang City. Padang, BMKG, (2010)

4. S. U, Intan, The Effect of the Tsunami Load on the New DPRD Building for the Province of West Sumatra, Padang, UNAND. (2017)
5. Regional Regulation of the City of Padang Number 7 of 2015 concerning Buildings, Padang (2015)

6. Department of Settlement and Regional Infrastructure, Indonesian Imposition of Regulations for Buildings (PPIUG) 1983, Jakarta, BSN (2002)

7. National Standardization Agency, SNI 1727: 2020. Minimum Load for Planning of Buildings and Other Structures, BSN, Jakarta (2020)

8. National Standardization Agency, SNI 1726:2019 Procedure for Planning Earthquake Resistance for Building Structures, BSN, Jakarta (2019)

9. Applied Technology Council, Guidelines for Design of Structures for Vertical Evacuation from Tsunamis, FEMA P646, California, FEMA (2019)

10. I. Muhammad, Analysis of the Effect of Earthquake and Tsunami Loads on 10-Story Reinforced Concrete Buildings Based on SNI 1727:2020 With Variations in Tsunami Heights, Palembang, UNSRI (2020)

11. R. E. Finesa, Vertical Evacuation Building Structure Design for Mitigation, Semarang, UNS (2015)

12. S. Agus, Design of Reinforced Concrete Structures (Based on SNI 2847:2013), Jakarta, Erlangga, (2016)

13. E. W. Peratundhika, Planning Structure for Case Studies: Building, TPTC (Teacher Professional Training Center) Padang State University, Padang, UNAND (2019)

14. Z. Syaifuddin, Structure Systems in High-rise Buildings, Surabaya, Humanities Foundation, (2011)

15. W. Sherlya, Identification of the Resilience of Evacuation Building Structures in Lambung Village Against Tsunami Loads, Medan, UNSYIAH (2021)

16. National Standardization Agency, Structural Concrete Requirements for Buildings, SNI 2847:2019, Jakarta, BSN (2019) 